\title{
REVIEW
}

\section{Basivertebral Nerve Ablation for the Treatment of Vertebrogenic Pain}

\author{
Ivan Urits (D) - Nazir Noor · Arjun Singh Johal · Joseph Leider • \\ Joseph Brinkman · Nathan Fackler · Neeraj Vij • Daniel An • \\ Elyse M. Cornett $\cdot$ Alan D. Kaye $\cdot$ Omar Viswanath
}

Received: August 7, 2020 / Accepted: October 8, 2020 / Published online: October 31, 2020

(C) The Author(s) 2020

\section{ABSTRACT}

Chronic low back pain affects a significant portion of patients worldwide and is a major contributor to patient disability; however, it is a difficult problem to diagnose and treat. The prevailing model of chronic low back pain has presumed to follow a discogenic model, but recent studies have shown a vertebrogenic model that involves the basivertebral nerve $(\mathrm{BVN})$. Radiofrequency ablation of the BVN has

Pertinent Topics and Relevant Updates in Pain Medicine.

I. Urits $(\square)$

Beth Israel Deaconess Medical Center, Department of Anesthesia, Critical Care, and Pain Medicine, Harvard Medical School, Boston, MA, USA e-mail: ivanurits@gmail.com

\section{N. Noor $\cdot$ N. Vij}

Department of Anesthesiology, Mount Sinai

Medical Center of Florida, Miami, FL, USA

A. S. Johal · O. Viswanath

Department of Anesthesiology, University of Arizona College of Medicine-Phoenix, Phoenix, AZ, USA

J. Leider · N. Fackler · D. An

Georgetown University School of Medicine,

Washington, DC, USA emerged as a possible nonsurgical therapy for vertebrogenic low back pain. The objective of this manuscript is to provide a comprehensive review of vertebrogenic pain diagnosis and our current understanding of BVN ablation as treatment.

Keywords: Basivertebral nerve; Basivertebral nerve ablation; Chronic low back pain; Low back pain; Radiofrequency ablation; Vertebrogenic pain 


\section{Key Summary Points}

Studies postulate that the pathophysiology of low back pain (LBP) may be vertebrogenic rather than only discogenic in origin.

Several studies have supported the safety, durability, and efficacy of radiofrequency ablation of the basivertebral nerve (BVN).

There is also convincing evidence that BVN ablation is more beneficial than current standard of care for the treatment of chronic LBP.

Further reproducible large clinical studies are needed to study BVN ablation before clinicians can confidently apply this treatment in their practice.

\section{DIGITAL FEATURES}

This article is published with digital features, including a summary slide, to facilitate understanding of the article. To view digital features for this article go to https://doi.org/10.6084/ m9.figshare.13060577.

\section{INTRODUCTION}

Low back pain (LBP) can be difficult to diagnose and treat. Lacking validated diagnostic reference standards, up to $85 \%$ of patients are diagnosed with nonspecific LBP [1-3]. Persistent LBP lasting longer than 12 weeks, known as chronic low back pain (CLBP), is often presumed to follow the discogenic model, which holds that there are sensitized nociceptors in the annulus fibrosus of degenerating disks that lead to discogenic pain [4-6]. However, there is growing evidence that damage to the highly innervated vertebral endplates can result in vertebrogenic pain (VBP) transmitted through branches of the basivertebral nerve $(\mathrm{BVN})$ and lead to acute or chronic pain, not exclusive to the back, as it can involve thoracic, lumbar, and/or sacral regions. This is an alternative to the discogenic ideology of lower back pain [7-11].

Immunohistochemical analysis has shown that there is a higher density of nociceptors that trace back to the BVN in damaged endplates compared to normal endplates and that the BVN contains substance P-, CGRP-, and PGP 9.5-positive nerve fibers, supporting the idea of the BVN's nociceptive role in the conduction of VBP $[7,12,13]$. Disc and endplate degeneration leads to increased communication between the vertebral bone marrow, resulting in the release of these inflammatory mediators and the appearance of Modic changes (MC) on magnetic resonance imaging (MRI) [10, 11, 14]. CLBP patients with MCs have been shown to be clinically different from those without, as patients with MCs report a greater frequency and duration of LBP episodes and have worse outcomes with conservative treatment and after discectomy [15-19]. To treat patients with CLBP associated with type 1 or $2 \mathrm{MCs}$, a minimally invasive procedure to ablate the $\mathrm{BVN}$ using radiofrequency energy was developed and shown to be safe and effective in initial pilot studies and randomized controlled trials (RCTs) [20-23]. The aim of this review is to summarize current literature on the epidemiology and risk factors, clinical presentation and diagnosis, pathophysiology, and anatomy of VBP and the use of BVN ablation in its treatment. This article is based on previously conducted studies and does not contain any studies with human participants or animals performed by any of the authors.

\section{EPIDEMIOLOGY AND RISK FACTORS}

LBP is highly prevalent both in the United States and globally. It affects approximately $30 \%$ of Americans at any given time, while $10-13 \%$ of the adult US population, or more than 30 million people, live with CLBP. Moreover it is the leading cause of disability worldwide [23-25]. LBP has been associated with population increases and aging, seeing a global rise in years lived with disability by $54 \%$ from 
1990 to 2015, mainly due to these two factors [26]. Modic changes can be seen on MRI in all spinal sections, with most MCs presenting in the lower lumbar levels and prevalence ranging from 5 to $62 \%$ of patients [27-30]. The prevalence of MCs is positively correlated with age, obesity status, and jobs that require heavy labor $[29,30]$.

\section{CLINICAL PRESENTATION AND DIAGNOSIS}

Annually, the prevalence of LBP in the US adult population is $10-30 \%$. The lifetime prevalence in US adults is as high as $65-80 \%$ [31]. LBP is the fifth most common reason for seeking medical care in the United States. The presentation of VBP will vary widely between patients, but they will generally complain of chronic pain in the lower back. The pain may be described as aching or burning, and may have associated electric shock sensations. The clinical presentation of LBP patients with MC may differ from LBP patients who lack MC [16]. Patients with LBP with $\mathrm{MC}$ are more likely to experience more frequent and longer LBP episodes and are also more likely to seek care [15]. These differences have led to the theory that there are different generators of pain and possibly different responses to treatment in LBP patients with MC [32-34]. The diagnosis of VBP is difficult and can be made with the visualization of $\mathrm{MC}$ on MRI.

The understanding of VBP is a relatively new concept, but there is a growing body of evidence that supports vertebral endplates as a source of LBP [9-11, 13]. The presence of nociceptors on endplates that trace back to the BVN was first illustrated in 1998 [35]. These endplates are inherently susceptible to damage. This damage may allow communication between the disc nucleus and vertebral bone marrow resulting in inflammation, which can be visualized as MC on an MRI [11]. The inflammation leads to endplate nerve proliferation, which in the presence of mechanical stimulation can result in pain signals transmitted to the $\mathrm{BVN}$, ultimately perceived as LBP [9]. It remains unclear why some patients develop MC and others do not. It is likely that the development of MC is a result of the composition and function of the bone marrow and its communication with the disc through the endplates.

\section{PATHOPHYSIOLOGY}

Immense progress has been made in the understanding of the pathophysiology behind VBP, and multiple recent studies have elucidated a possible mechanism for the development of MC. Cytokines have been suggested to play a major role. Discs adjacent to MC produce higher amounts of cytokines and osteoclastic factors than discs with the same degree of degeneration without adjacent MC [10, 36]. These cytokines modulate the cellular composition of surrounding bone marrow and alter trabecular bone mass. Therefore, bone formation/resorption is a transient or individual phenomenon depending on the activity of osteocytes and osteoclasts. Toll-like receptor (TLR) stimulation of disc and marrow cells may also play a role in the development of MC. Degenerated discs show increased expression of TLRs compared to non-degenerated discs $[37,38]$. TLR activation enhances transcription of NF-кB-responsive genes, a central signaling pathway in both degenerative disc disease and osteoarthritis [39]. TLR signaling modulates T-cell activity and autoimmunity [40]. TLRs are also activated by damage-associated molecular patterns (DAMPs). DAMPs are molecules released from necrotic cells or generated after mechanical or enzymatic tissue damage. ECM components, including fibronectin and hyaluronic acid fragments, are DAMPs that play a crucial role in osteoarthritis [39]. The response of the BM to cytokines and DAMPs leaking from the disc through endplate defects into the $\mathrm{BM}$ depends on the composition of the BM itself. Vertebral marrow adipose tissue is higher in males and older individuals and is most prominent in the lumbar spine [41]. These three factors are also associated with the prevalence of MC [42]. The saturated fatty acids in vertebral marrow adipose tissue activate certain TLRs $[39,41]$. ECM fragments spilling from a degenerated disc into a bone marrow that is highly 
concentrated with fatty acids will increase the total concentration of TLR ligands and NF-кBcontrolled cytokines. The enzymatic process generates abundant ECM catabolites and DAMPs, which may lead to the generation of MC in these patients. Chronic stimulation of TLRs was demonstrated to generate adipose tissue and induce hypertrophy of adipocytes $[43,44]$. The relationship between fat metabolism and marrow composition in the generation of MCs is unknown, but many parallels can be drawn to bone marrow lesions in osteoarthritis. MCs adjacent to a degenerated disc share many characteristics with bone marrow lesions in the femur and tibia of an osteoarthritic knee. High serum lipids, obesity, age, and male gender increase the risk of developing bone marrow lesions [45]. Therefore, knowledge from both osteoarthritis and bone marrow lesions research at peripheral skeletal sites may help elucidate the pathobiology of MC.

\section{ANATOMY}

There are several important aspects of the anatomy of the spinal column when considering both the pathogenesis of VBP and the subsequent treatment.

Though it is well known that disc injury caused by chronic degeneration of the disc is a common cause of CLBP, the source of the pain is still not completely understood. This study used protein gene product 9.5 (PGP 9.5) to determine the anatomical location of the nerve fibers within the vertebral body. Though it is known that the central vertebral endplate is highly innervated and that overactivity in these neurons is considered to be the source of back pain in patients with degenerative disc disease, the anatomical relationship of these nerve fibers is not well understood. Bailey et al. sought to determine the spatial pattern regarding the nerve fibers in the vertebral body of the L4 lumbar vertebrae [12]. They found that the nerves were adjacent to the blood vessels and that they enter posteriorly via the basivertebral foramen and cluster in the vertebral center. These sinuvertebral nerves, which likely accompany the nutrient artery into the vertebral body, are an important potential source and target for treatment [46]. This is in agreement with what was previously believed. The high degree of innervation of the bony vertebral endplate supports the idea that these nerves may be the source of vertebrogenic nerve pain. It also suggests that immune histological staining with the calcitonin gene-related protein will co-localize with PGP 9.5 and that this can be used to study the spatial distribution pattern of nerves within the vertebrae [12].

The sinuvertebral nerve is formed by the combination of the somatic root from the ventral ramus and an autonomic root from the grey ramus [47]. Grey rami give rise to the autonomic roots to form the vertebral nerve, while the thoracic and lumbar levels receive somatic roots to form the vertebral nerve [47].

Zhao et al. shed further light on the anatomy of the sinuvertebral nerves within the lumbar vertebrae [46]. The authors found that the sinuvertebral nerves divide into a deputy branch and main trunk. They also found that the deputy branch divides into an average of 3.12 branches. The main trunks were nearly always found in the intervertebral foramina, and the initial portion was located along the posterolateral edge of the disc. As the anatomy of the lumbar vertebrae has only recently been uncovered, further studies should be done to corroborate this and to understand how we can implement this knowledge with regard to treatment [46].

Apart from the lumbar vertebrae, it is suspected that the S1 vertebrae may play a large role in the pathogenesis of VBP. It is well known that the L5-S1 intervertebral disc has high biomechanical loading, simply considering the change in curvature that occurs at this point. Surgical correction of the disc at this location is common. However, the innervation patterns at this site may be different from those in the lumbar vertebrae.

The S1 site does have an apparent nutrient foramen on the posterior border, and it has also been determined that the S1 vertebral body is innervated by a dense set of nerves. However, the nerves in the $S 1$ vertebral body are located specifically in the mid-lateral borders of the vertebral body. These nerves branch from the 
anterior sacral nerve and are thought to enter from the sacral foramen. This anatomical relationship is likely unique to the $\mathrm{S} 1$ vertebrae and may be related to its potential as a source of VBP.

This unique anatomy of the S1 vertebrae needs to be considered not only in regard to the pathogenesis of VBP, but also in regard to the treatment. Treatments aimed at addressing the root cause need to address the clustering of nerve fibers seen in the lateral and inferior borders of the vertebral borders [48]. It is also important to note that the anatomy of the vertebral column varies throughout the population. Variables that have a range within the population regarding VBP include pelvic incidence, pelvic tilt, and sacral slope [49].

These spinopelvic parameters may be related to changes that we see in patients such as disc displacement, Modic changes, and even the presence of a diagnostic ultra-short time-toecho (UTE) disc sign (UDS) on MRI. This indicates that varying anatomy within the population may explain why some phenotypes are clinically significant and others are not. This may also be related to the development of CLBP in some patients and not others. Additional research is needed to determine this relationship and how anatomy can be further studied to optimize treatment [49].

\section{BASIVERTEBRAL NERVE ABLATION FOR THE TREATMENT OF VERTEBROGENIC PAIN}

The role of the BVN in the pathophysiology of CLBP has been well established. In 1997, Brown and colleagues suggested that endplates were a source of CLBP in patients with degenerative disk disease after finding an increased density of nociceptors in endplate cartilage defects [50]. The following year, Antonacci et al. postulated the role of BVN in CLBP after mapping the nerves in relation to vertebral bodies and finding their course with the nutrient arteries and endplate branches [35]. Further investigations specified BVN morphology in relation to their entry through posterior foramina using PGP9.5 staining [12]. However, their direct role in transmitting pain signals was not formally established until substance $P$ was stained for within the nerves [13]. Together, these findings provided an explanation that some LBP is likely vertebrogenic, rather than only discogenic, in origin. Consequently, targeting this pain through ablation of the BVN emerged as a promising treatment and has been supported by various investigations (Table 1 ).

In a 2017 single-arm multicenter study, Becker et al. assessed the safety and efficacy of $B V N$ radiofrequency (RF) ablation in 17 patients with CLBP. Each patient had back pain for longer than 6 months that was nonresponsive to at least 3 months of conservative medical care. Patients that had any spine surgery, malignancy, scoliosis, or infection were excluded from the study. Treatment levels were identified via MRI evidence of Modic type 1 or 2 changes and were limited to the L3-S1 levels. Primary outcome measures for successful treatment included improvement in disability as defined by the Oswestry Disability Index (ODI) maintenance of baseline neurological status on follow-up, and lack of procedure-related serious adverse events (SAEs). Notable secondary measures included pain as measured by the visual analog pain scale (VAS) and general health and quality of life status measured by the Medical Outcomes Study 36-Item Short Form Survey (SF36) [51]. All 17 patients were observed for 12 months following treatment to assess changes in primary and secondary outcome measures. The mean ODI in the treated cohort decreased from 52 before treatment to 23 at 3 months $(p<0.001)$ and remained statistically significant throughout 1 year. Additionally, both VAS and SF-36 scores improved significantly $(p<0.05$ and $p=0.03$, respectively) at 6-week and 3-month follow-up. Finally, no changes were found on neurological exam, and no SAEs were reported. This study concluded that there was sufficient evidence to support BVN ablation for CLBP, and an RCT was under way for further investigation [52].

Truumees et al. conducted a similar singlearm multicenter study examining the efficacy of BVN ablation for CLBP greater than 6 months with Modic type 1 or 2 endplate changes between the L3 and S1 vertebrae. Twenty-eight 
Table 1 Basivertebral nerve ablation for vertebrogenic back pain

\begin{tabular}{|c|c|c|c|}
\hline Authors & $\begin{array}{l}\text { Groups studied and } \\
\text { intervention }\end{array}$ & Results and findings & Conclusions \\
\hline Khalil et al. [22] & $\begin{array}{l}140 \text { patients with chronic } \\
\text { lumbar back pain with } \\
\text { vertebral endplate changes } \\
\text { between L3 and S1 were } \\
\text { randomized to undergo } \\
\text { standard care or } \\
\text { radiofrequency (RF) ablation } \\
\text { of the BVN }\end{array}$ & $\begin{array}{l}\text { Patient-reported outcome } \\
\text { measures were significantly } \\
\text { higher in the RF group; } \\
74.5 \% \text { of patients in the RF } \\
\text { group had > 10-point } \\
\text { improvement in the } \\
\text { Oswestry Disability Index } \\
\text { (ODI), compared with } \\
32.7 \% \text { in the standard care } \\
\text { group. Changes in ODI } \\
\text { scores for the RF and control } \\
\text { groups at } 3 \text { months were } \\
-25.3 \text { and }-4.4 \text { points, } \\
\text { respectively }\end{array}$ & $\begin{array}{l}\text { RF ablation of the BVN } \\
\text { showed significant } \\
\text { improvement in patient- } \\
\text { reported pain and } \\
\text { function at } 3 \text { months in } \\
\text { patients with chronic } \\
\text { lumbar back pain of } \\
\text { vertebrogenic origin }\end{array}$ \\
\hline Fischgrund et al. [58] & $\begin{array}{l}225 \text { patients diagnosed with } \\
\text { chronic lumbar back pain } \\
\text { were randomized to BVN } \\
\text { ablation or sham treatment }\end{array}$ & $\begin{array}{l}\text { The average decrease in ODI } \\
\text { was } 20.5 \text { and } 15.2 \text { points in } \\
\text { the treatment and sham } \\
\text { groups, respectively } \\
(p=0.019) .75 .6 \% \text { of } \\
\text { patients in the treatment } \\
\text { group exhibited clinical } \\
\text { improvement at } 3 \text { months }\end{array}$ & $\begin{array}{l}\text { Patients undergoing RF } \\
\text { ablation of BVN for } \\
\text { chronic lumber back pain } \\
\text { demonstrated significant } \\
\text { improvement in ODI at } \\
3 \text { months and a higher } \\
\text { response rate when } \\
\text { compared to the control } \\
\text { arm. This modality } \\
\text { appears to be a successful } \\
\text { minimally invasive } \\
\text { treatment of chronic } \\
\text { lumbar back pain }\end{array}$ \\
\hline
\end{tabular}


Table 1 continued

\begin{tabular}{|c|c|c|c|}
\hline Authors & $\begin{array}{l}\text { Groups studied and } \\
\text { intervention }\end{array}$ & Results and findings & Conclusions \\
\hline Fischgrund et al. [21] & $\begin{array}{l}147 \text { patients with chronic } \\
\text { lumbar back pain were } \\
\text { randomized to RF ablation } \\
\text { of the BVN in an RCT }\end{array}$ & $\begin{array}{l}\text { Patients in the RF group } \\
\text { showed statistically } \\
\text { significant improvement in } \\
\text { the ODI, visual analog scale } \\
\text { (VAS), and Medical } \\
\text { Outcomes Trust Short-Form } \\
\text { Health Survey Physical } \\
\text { Component Summary at all } \\
\text { follow-up points through } \\
2 \text { years. Compared to } \\
\text { baseline, the mean percentage } \\
\text { improvement in VAS and } \\
\text { ODI at } 2 \text { years was } 52.9 \text { and } \\
53.7 \% \text {, respectively }\end{array}$ & $\begin{array}{l}\text { Patients with chronic } \\
\text { lumbar back pain treated } \\
\text { with RF ablation of the } \\
\text { BVN demonstrated } \\
\text { sustained clinical benefits } \\
\text { in ODI and VAS at } \\
2 \text { years post-treatment. } \\
\text { Ablation of the BVN } \\
\text { appears to be a reliable } \\
\text { and durable treatment for } \\
\text { chronic lumbar back pain }\end{array}$ \\
\hline Kim et al. [65] & $\begin{array}{l}14 \text { patients with chronic } \\
\text { lumbar back pain with } \\
\text { positive MRI findings of } \\
\text { Modic type } 1 \text { or } 2 \text { changes } \\
\text { underwent transforaminal } \\
\text { BVN laser ablation }\end{array}$ & $\begin{array}{l}\text { The mean preoperative VAS } \\
\text { score of } 7.79 \text { was reduced to } \\
1.92 \text { at a mean follow-up of } \\
15 \text { months. Seven patients } \\
\text { had excellent outcomes, six } \\
\text { had good outcomes, and one } \\
\text { had fair outcomes per } \\
\text { Macnab criteria }\end{array}$ & $\begin{array}{l}\text { Transforaminal BVN } \\
\text { ablation is a promising } \\
\text { treatment option for } \\
\text { patients with CLBP and } \\
\text { accompanying Modic } \\
\text { changes }\end{array}$ \\
\hline Kim et al. [66] & $\begin{array}{l}30 \text { patients with intervertebral } \\
\text { disc or spinal stenosis } \\
\text { underwent endoscopic RF } \\
\text { ablation of basivertebral and } \\
\text { sinuvertebral nerves }\end{array}$ & $\begin{array}{l}\text { Patients showed statistically } \\
\text { significant improvement in } \\
\text { VAS and ODI at } 1 \text { week, } \\
6 \text { months, and final follow- } \\
\text { up }(p<0.0001 \text {, } \\
p<0.0001) \text {. Of the } 30 \\
\text { patients, } 17 \text { had excellent and } \\
11 \text { had good outcomes per } \\
\text { Macnab criteria }\end{array}$ & $\begin{array}{l}\text { Ablation of both BVN and } \\
\text { sinuvertebral nerve were } \\
\text { effective in significantly } \\
\text { improving pain and } \\
\text { function. Further } \\
\text { investigation into ablation } \\
\text { of both nerves is } \\
\text { warranted }\end{array}$ \\
\hline
\end{tabular}


Table 1 continued

\begin{tabular}{|c|c|c|c|}
\hline Authors & $\begin{array}{l}\text { Groups studied and } \\
\text { intervention }\end{array}$ & Results and findings & Conclusions \\
\hline Wu et al. [69] & $\begin{array}{l}\text { Review and summary of } \\
\text { intervertebral disc disease, } \\
\text { BVN association with back } \\
\text { pain, and role of BVN and } \\
\text { sinuvertebral ablation to } \\
\text { offer relief through } \\
\text { minimally invasive means }\end{array}$ & $\begin{array}{l}\text { BVN and sinuvertebral nerves } \\
\text { are infiltrated with } \\
\text { granulation tissue in response } \\
\text { to increased cytokines in } \\
\text { degenerative disc disease } \\
\text { (DDD), leading to the } \\
\text { production of pain in } \\
\text { response to DDD. Ablation } \\
\text { of these nerves offers relief in } \\
\text { select patients }\end{array}$ & $\begin{array}{l}\text { BVN and/or sinuvertebral } \\
\text { ablation should be } \\
\text { included in the treatment } \\
\text { algorithm for patients } \\
\text { with late DDD and } \\
\text { concomitant positive } \\
\text { discography }\end{array}$ \\
\hline Lorio et al. [23] & $\begin{array}{l}\text { International Society for the } \\
\text { Advancement of Spine } \\
\text { Surgery guideline } \\
\text { establishment through } \\
\text { summarizing high-quality } \\
\text { studies of BVN ablation }\end{array}$ & $\begin{array}{l}\text { Intraosseous BVN ablation is } \\
\text { supported by basic clinical } \\
\text { evidence, a level } 1 \text { sham- } \\
\text { controlled RCT, and a } \\
\text { subsequent RCT compared } \\
\text { to standard conservative } \\
\text { treatment }\end{array}$ & $\begin{array}{l}\text { The treatment is durable, } \\
\text { safe, and is justified as a } \\
\text { treatment option for } \\
\text { CLBP patients who meet } \\
\text { certain criteria of } \\
\text { symptom duration, } \\
\text { refractoriness, and Modic } \\
\text { changes }\end{array}$ \\
\hline Becker et al. [52] & $\begin{array}{l}17 \text { patients with CLBP and } \\
\text { Modic type } 1 \text { or } 2 \text { endplate } \\
\text { changes confirmed by MRI }\end{array}$ & $\begin{array}{l}\text { Statistically significant } \\
\text { improvements were made in } \\
\text { all outcome measurements } \\
\text { including ODI }(p<0.001) \text {, } \\
\text { VAS }(p<0.05) \text {, and SF-36 } \\
(p=0.03) \text { at } 3 \text {-month } \\
\text { follow-up }\end{array}$ & $\begin{array}{l}\text { Ablation of BVN for CLBP } \\
\text { significantly improved } \\
\text { patient-reported outcome } \\
\text { in the early follow-up } \\
\text { period, with results } \\
\text { sustained throughout the } \\
\text { 1-year study period }\end{array}$ \\
\hline Truumees et al. [54] & $\begin{array}{l}28 \text { patients with CLBP and } \\
\text { Modic type } 1 \text { or } 2 \text { endplate } \\
\text { changes that received BVN } \\
\text { ablation and were followed } \\
\text { up for a minimum of } \\
12 \text { months }\end{array}$ & $\begin{array}{l}\text { Average ODI of treated } \\
\text { patients at } 3 \text {-month follow- } \\
\text { up decreased from } 48.5 \text { pre- } \\
\text { treatment to } 14.52 \text { post- } \\
\text { treatment, a difference of } \\
30.07 \text { points }(p<0.0001) \text {. } \\
78.6 \% \text { of patients considered } \\
\text { the treatment a success }\end{array}$ & $\begin{array}{l}\text { Minimally invasive BVN RF } \\
\text { ablation significantly } \\
\text { improved pain and } \\
\text { function in real-world } \\
\text { patients with CLBP }\end{array}$ \\
\hline
\end{tabular}


Table 1 continued

\begin{tabular}{|c|c|c|c|}
\hline Authors & $\begin{array}{l}\text { Groups studied and } \\
\text { intervention }\end{array}$ & Results and findings & Conclusions \\
\hline Markmann et al. [63] & $\begin{array}{l}45 \text { patients with CLBP that } \\
\text { were randomized to either } \\
\text { sham or RF ablation while } \\
\text { also managing their pain } \\
\text { with opioid medication }\end{array}$ & $\begin{array}{l}\text { Patients treated with BVN } \\
\text { ablation who subsequently } \\
\text { decreased their dose of } \\
\text { opioid medication showed a } \\
\text { significant improvement in } \\
\text { VAS and ODI scores } \\
\text { compared to those who } \\
\text { received BVN ablation and } \\
\text { did not decrease their dose of } \\
\text { opioid medication }\end{array}$ & $\begin{array}{l}\text { There is an association } \\
\text { between functional } \\
\text { improvement following } \\
\text { BVN ablation and taking } \\
\text { lower doses of opioid } \\
\text { medication }\end{array}$ \\
\hline
\end{tabular}

patients were studied, with a minimum followup of 12 months. The inclusion and exclusion criteria for patients were similar to those of Becker et al., with the notable exception of allowing patients who had received a laminectomy or discectomy at least 6 months prior to their enrollment in the study. The primary outcome measure was ODI, and the secondary outcome measures were VAS and quality of life, including SF-36 and EQ-5D-3L [53]. Successful treatment was defined as a 10-point change in ODI from baseline. Mean ODI in the 28 treated patients decreased from 48.50 before treatment to 18.42 at the 3 -month follow-up $(p<0.0001)$, an average 30.07-point change. At 3 months, $26 / 28$ patients had met the threshold for successful treatment. Importantly, this study assessed patient satisfaction with the procedure and noted that $78.6 \%$ of patients stated that the procedure was a success, and $85.7 \%$ of patients stated that they would have BVN ablation done again for the same condition [54].

Fischgrund et al. conducted one of the largest studies to date evaluating BVN ablation for the treatment of CLBP. This prospective, multicenter, double-blind investigation involved randomization of 225 patients to sham treatment or RF BVN ablation through transpedicular delivery. Similar to previous investigations,
CLBP was defined as greater than 6 months of isolated lumbar pain that was refractory to conservative treatment. The treatment levels of interest were restricted to two to three consecutive vertebral body levels anywhere from L3 to S1. Accordingly, Modic type 1 or 2 changes, as indicated by degenerative endplate bone marrow findings, were required as part of the inclusion criteria [55]. Other relevant inclusion criteria related to patient selection included a minimum score of 30 on the ODI and 4 on the VAS $[56,57]$. The average decrease in the ODI of the 147 patients in the treatment group was 20.5 at 3 -month follow-up. This was significantly greater improvement than demonstrated in the sham treatment group, which showed an average decrease of $15.2(p=0.019)$. A minimal clinically important difference (MCID), based on the commonly accepted 10-point improvement in ODI, was achieved by $75.6 \%$ of patients in the treatment arm and $55.4 \%$ in the control group. Similarly, VAS scores were significantly improved in the treatment arm at 3-, 6-, and 12-month follow-up $(p=0.083,0.008$, and 0.038). The authors concluded that their data supported BVN ablation as a potential minimally invasive intervention to address CLBP [58]. 
In a separate follow-up report, Fischgrund and colleagues published findings on the same patients at 24-month follow-up. The investigation was conducted as part of a Food and Drug Administration-approved investigational device exemption trial and involved evaluations, patient self-assessments, safety assessments, physical examinations, and neurological examinations at postoperative months $3,6,12,18$, and 24. The results continued to support RF BVN ablation even at this prolonged follow-up interval. The 3-month MCID rate of $75.6 \%$ achieved in the treatment group was sustained at 24 months, with a resulting MCID pass rate of $76.4 \%$. Likewise, VAS improvement was sustained at 24 months, with $70.2 \%$ of the treatment group meeting or exceeding a $1.5 \mathrm{~cm}$ improvement in VAS. Moreover, a significant clinical benefit over baseline was reported at each time point throughout the 2-year study. This extended study prompted the authors to conclude that BVN ablation is a safe, durable, and effective treatment method for the relief of CLBP in patients with Modic type 1 or 2 changes [21]. Of note, Fischgrund later published a follow-up letter to the editor to clarify specifics on this topic. Namely, he noted that subset analyses showed no differences in outcome between patients whose treatment did and did not include the S1 level. He further noted that the treatment arm showed a clinical as well as statistical benefit, as determined by the ODI and VAS outcomes, and reaffirmed the safety and efficacy of BVN ablation for treating CLBP of vertebrogenic origin [59].

In a large multicenter RCT involving 140 patients, Khalil et al. compared the effectiveness of BVN ablation to the standard of care for CLBP. Using similar inclusion criteria as prior studies, the RCT included patients with back pain for a minimum of 6 months with Modic type 1 or 2 endplate changes to levels L3-S1. A wide range of exclusion criteria was set; notably, patients with prior lumbar spine surgery and symptomatic spinal stenosis (confirmed with imaging) were excluded. The outcome measures of this study remained similar to other studies, with the primary outcome being a change in ODI and secondary outcomes comprising changes in VAS, SF-36, and EQ-5D-5L. Patients were randomized into two groups, 70 receiving $\mathrm{RF}$ ablation and 70 receiving current standard of care including, but not limited to, pain medications, physical therapy, exercise, spinal injections, and acupuncture. Differences in demographics were analyzed between the treatment and control groups, and there was no statistically significant difference between the two among any subgroup. Patients were assessed at 3, 6, 9, and 12 months following treatment. An interim analysis was performed after 104 of the 140 had completed their 3-month follow-up, and showed statistical superiority in all outcome measures in the RF ablation group $(p<0.001)$. A change of $>10$ points in ODI was found in $74.5 \%$ of patients in the RF group, compared with $32.7 \%$ in the control group. The mean change in ODI score in the RF and control groups at 3 months was -25.3 and -4.4 points, respectively. Following that analysis, the study halted enrollment of new participants and offered patients in the standard-of-care arm early crossover into the RF ablation arm [22]. Khalil et al. expressed optimism that the benefits of RF ablation would be sustained beyond 3 months as they were through 24 months in the sham trial by Fischgrund et al. [20]. In response to the publication of this trial, Wong et al. expressed enthusiasm for the potential benefit that this new technology would bring to their patients but cited Scott's parabola to caution providers to wait until the results of this trial had been reproduced over multiple RCTs before applying it to their practice $[60,61]$.

The appropriate use of opioid medication is an important consideration in patients undergoing BVN ablation, as opioids are the most frequently prescribed medication for patients with CLBP [62]. Markman et al. conducted a post hoc analysis of 45 patients enrolled in a previous trial examining the effects of BVN ablation on CLBP, in order to assess the efficacy of opioid use in patients receiving BVN ablation. Two external reviewers who were blinded to treatment (sham vs. active treatment) were asked to group patients based on changes in their opioid usage following treatment. A change in usage was defined as an increase or decrease of 10 morphine milligram equivalent (MME) per day. These patients were then 
stratified into three groups (increased, decreased, or unchanged dosage), and differences in ODI and VAS measurements between the groups were analyzed. In the treatment group, those who decreased their opioid use following BVN ablation reported significant improvements in VAS and ODI scores compared to those who increased their opioid dose following BVN ablation. The sham group did not demonstrate a significant difference in VAS or ODI scores related to opioid dosage. The authors concluded that their results support the idea that patient outcomes are more likely to improve if their opioid dose is decreased rather than increased following BVN ablation [63].

Kim and colleagues designed a similar study in 2018. However, the researchers were specifically interested in demonstrating the efficacy of BVN ablation utilizing laser rather than RF, using a transforaminal targeting approach. The study arm included 14 CLBP patients who failed conservative management and who had demonstrated Modic type 1 or 2 changes on MRI, confirmed with provocative discography. Laser-assisted ablation of the BVN was achieved through a transforaminal approach. Outcomes of interest were the VAS and Macnab criteria [64]. Over a mean follow-up of 15.3 months, preoperative VAS scores improved from 7.79 to 1.92. Of the 14 patients, seven had excellent outcomes, six had good outcomes, and one had a fair outcome based on the Macnab criteria. With these results in mind, the authors concluded that the transforaminal approach with laser ablation is a promising option for patient populations represented in the study [65].

In a subsequent study, Kim et al. analyzed RF ablation of both the BVN and sinuvertebral nerve in patients with chronic back pain of discogenic origin. The inclusion of sinuvertebral nerve ablation was supported by noting its proven association with the pain pathway and the authors' belief that it is associated with nerves adjacent to a bulging disc [47]. The study involved 30 patients and 38 vertebral levels with degenerative intervertebral discs or spinal stenosis. Similar to other investigations, outcomes collected included VAS, ODI, and the Macnab criteria. The results demonstrated improvement in VAS and ODI at the 1-week, 6-month, and final (average of 14.9 months) follow-up ( $p<0.0001, p<0.0001)$. According to the Macnab criteria, 17 had excellent outcomes, 11 had good outcomes, and 2 had fair outcomes. The authors subsequently concluded that ablation of both the sinuvertebral and BVN through RF is effective in improving pain and disability status [66].

Following the abovementioned report, $\mathrm{Wu}$, along with Kim et al., conducted a comprehensive review of the diagnosis and treatment of intervertebral disc disease. They initially summarized the role of increased proinflammatory and cytokine activity in degenerative disc disease. They noted that BVN and sinuvertebral nerves are infiltrated with granulation tissue in response to these cytokines, leading to the production of pain in response to degenerative disc disease [65-68]. The authors subsequently suggested RF ablation of the sinuvertebral or BVN as a reliable, definitive, and minimally invasive palliative strategy to manage axial back pain. As such, it is included in their treatment algorithm for patients with late degenerative disc disease and concomitant positive discography [69].

In a separate review, Lorio et al. summarized intraosseous ablation of the BVN for CLBP as part of the treatment guidelines established by the International Society for the Advancement of Spine Surgery. The authors highlight the key findings of the studies addressed in this section. The report concludes that intraosseous BVN ablation is supported by basic clinical evidence, including a level 1 sham-controlled RCT and a subsequent level 1 RCT, as an alternative to standard conservative treatment. The authors note that the treatment is durable at 2 years, safe, and justified as a treatment option for patients with CLBP persisting for 6 months refractory to conservative treatment and with MRI-proven Modic changes [23].

\section{CONCLUSION}

CLBP is a difficult yet common diagnosis that affects a significant portion of patients worldwide. In efforts to combat this debilitating disease, researchers have made great progress in 
understanding the pathophysiology of LBP in addition to unveiling the anatomy of the vertebrae in search of appropriate treatment options. As a result, with the growing evidence supporting the vertebrogenic model that involves the BVN, RF ablation of the BVN has emerged as a possible minimally invasive procedure to treat LBP. Several studies have supported the safety, durability, and efficacy of RF ablation of the BVN. There is also convincing evidence that BVN ablation is more beneficial than the current standard of care for the treatment of CLBP. However, reproducible large RCTs are still needed for clinicians to gain full confidence in utilizing this treatment in practice. Additionally, further research is needed on the anatomy of the vertebrae to optimize the method of treatment. These studies can help to elucidate the role of RF ablation in the management of CLBP and improve the quality of life of CLBP patients in the near future.

\section{ACKNOWLEDGEMENTS}

Funding. No funding or sponsorship was received for this study or publication of this article.

Authorship. All named authors meet the International Committee of Medical Journal Editors (ICMJE) criteria for authorship for this article, take responsibility for the integrity of the work as a whole, and have given their approval for this version to be published.

Disclosures. Ivan Urits, Nazir Noor, Arjun Singh Johal, Joseph Leider, Joseph Brinkman, Nathan Fackler, Neeraj Vij, Daniel An, and Elyse M. Cornett have nothing to disclose. Alan D. Kaye and Omar Viswanath are members of the journal's Editorial Board.

Compliance with Ethics Guidelines. This article is based on previously conducted studies and does not contain any studies with human participants or animals performed by any of the authors.
Open Access. This article is licensed under a Creative Commons Attribution-NonCommercial 4.0 International License, which permits any non-commercial use, sharing, adaptation, distribution and reproduction in any medium or format, as long as you give appropriate credit to the original author(s) and the source, provide a link to the Creative Commons licence, and indicate if changes were made. The images or other third party material in this article are included in the article's Creative Commons licence, unless indicated otherwise in a credit line to the material. If material is not included in the article's Creative Commons licence and your intended use is not permitted by statutory regulation or exceeds the permitted use, you will need to obtain permission directly from the copyright holder. To view a copy of this licence, visit http://creativecommons.org/licenses/by$\mathrm{nc} / 4.0 /$.

\section{REFERENCES}

1. Deyo RA, Weinstein JN. Low back pain. N Engl J Med. 2001;344(5):363-70.

2. Chou R, Qaseem A, Owens DK, Shekelle P, Clinical Guidelines Committee of the American College of Physicians. Diagnostic imaging for low back pain: advice for high-value health care from the American College of Physicians. Ann Intern Med. 2011;154(3):181.

3. Chou R, Qaseem A, Snow V, Casey D, Cross JT, Shekelle $\mathrm{P}$, et al. Diagnosis and treatment of low back pain: a joint clinical practice guideline from the American College of Physicians and the American Pain Society. Ann Intern Med. 2007;147(7): 478.

4. DePalma MJ, Ketchum JM, Saullo T. What is the source of chronic low back pain and does age play a role? Pain Med. 2011;12(2):224-33.

5. Schwarzer AC, Aprill CN, Derby R, Fortin J, Kine G. The relative contributions of the disc and zygapophyseal joint in chronic low back pain. Spine (Phila Pa 1976). 1994;19(7):801-6.

6. Manchikanti L, Singh V. Evaluation of the relative contributions of various structures in chronic low back pain. Pain Phys. 2001;4:308-16. 
7. Fagan A, Moore R, Vernon Roberts B, Blumbergs P, Fraser R. ISSLS prize winner: the innervation of the intervertebral disc: a quantitative analysis. Spine (Phila Pa 1976). 2003;28(23):2570-6.

8. Van Dieën JH, Weinans H, Toussaint HM. Fractures of the lumbar vertebral endplate in the etiology of low back pain: a hypothesis on the causative role of spinal compression in aspecific low back pain. Med Hypotheses. 1999;53(3):246-52.

9. Lotz JC, Fields AJ, Liebenberg EC. The role of the vertebral end plate in low back pain. Glob Spine J. 2013;3(3):153-63.

10. Dudli S, Fields AJ, Samartzis D, Karppinen J, Lotz JC. Pathobiology of Modic changes. Eur Spine J. 2016;25(11):3723-34.

11. Dudli S, Sing DC, Hu SS, Berven SH, Burch S, Deviren $\mathrm{V}$, et al. ISSLS PRIZE IN BASIC SCIENCE 2017: intervertebral disc/bone marrow cross-talk with Modic changes. Eur Spine J. 2017;26(5): 1362-73.

12. Bailey JF, Liebenberg E, Degmetich S, Lotz JC. Innervation patterns of PGP 9.5-positive nerve fibers within the human lumbar vertebra. J Anat. 2011;218(3):263-70.

13. Fras C, Kravetz P, Mody DR, Heggeness MH. Substance P-containing nerves within the human vertebral body: an immunohistochemical study of the basivertebral nerve. Spine J. 2003;3(1):63-7.

14. Ulrich JA, Liebenberg EC, Thuillier DU, Lotz JC. ISSLS prize winner: repeated disc injury causes persistent inflammation. Spine (Phila $\mathrm{Pa}$ 1976). 2007;32(25):2812-9.

15. Kjaer P, Korsholm L, Bendix T, Sorensen JS, Leboeuf-Yde C. Modic changes and their associations with clinical findings. Eur Spine J. 2006;15(9): 1312-9.

16. Jensen TS, Karppinen J, Sorensen JS, Niinimäki J, Leboeuf-Yde C. Vertebral endplate signal changes (Modic change): a systematic literature review of prevalence and association with non-specific low back pain. Eur Spine J. 2008;17:1407-22.

17. Jensen RK, Leboeuf-Yde C. Is the presence of Modic changes associated with the outcomes of different treatments? A systematic critical review. BMC Musculoskelet Disord BioMed Central. 2011;12: 183.

18. Jensen OK, Nielsen CV, Sørensen JS, StengaardPedersen K. Type 1 Modic changes was a significant risk factor for 1-year outcome in sick-listed low back pain patients: a nested cohort study using magnetic resonance imaging of the lumbar spine. Spine J. 2014;14(11):2568-81.

19. Lurie JD, Moses RA, Tosteson ANA, Tosteson TD, Carragee EJ, Carrino JA, et al. Magnetic resonance imaging predictors of surgical outcome in patients with lumbar intervertebral disc herniation. Spine (Phila Pa 1976). 2013;38(14):1216-25.

20. Fischgrund JS, Rhyne A, Franke J, Sasso R, Kitchel S, Bae $\mathrm{H}$, et al. Intraosseous basivertebral nerve ablation for the treatment of chronic low back pain: a prospective randomized double-blind sham-controlled multi-center study. Eur Spine J. 2018;27(5): 1146-56.

21. Fischgrund JS, Rhyne A, Franke J, Sasso R, Kitchel S, $\mathrm{Bae} \mathrm{H}$, et al. Intraosseous basivertebral nerve ablation for the treatment of chronic low back pain: 2 -year results from a prospective randomized double-blind sham-controlled multicenter study. Int J Spine Surg. 2019;13(2):110-9.

22. Khalil JG, Smuck M, Koreckij T, Keel J, Beall D, Goodman B, et al. A prospective, randomized, multicenter study of intraosseous basivertebral nerve ablation for the treatment of chronic low back pain. Spine J. 2019;19(10):1620-32.

23. Lorio M, Clerk-Lamalice O, Beall DP, Julien T. International Society for the Advancement of Spine Surgery Guideline-intraosseous ablation of the basivertebral nerve for the relief of chronic low back pain. Int J Spine Surg. 2020;14(1):18-25.

24. Shmagel A, Foley R, Ibrahim H. Epidemiology of chronic low back pain in US Adults: data from the 2009-2010 National Health and Nutrition Examination Survey. Arthritis Care Res (Hoboken). 2016;68(11):1688-94.

25. Freburger JK, Holmes GM, Agans RP, Jackman AM, Darter JD, Wallace AS, et al. The rising prevalence of chronic low back pain. Arch Intern Med. 2009;169(3):251-8.

26. Hartvigsen J, Hancock MJ, Kongsted A, Louw Q, Ferreira ML, Genevay S, et al. What low back pain is and why we need to pay attention. Lancet. 2018;391:2356-67.

27. Wang Y, Videman T, Battié MC. Modic changes: prevalence, distribution patterns, and association with age in white men. Spine J. 2012;12(5):411-6.

28. Zhang YH, Zhao CQ, Jiang LS, Chen XD, Dai LY. Modic changes: a systematic review of the literature. Eur Spine J. 2008;17:1289-99.

29. Mok FPS, Samartzis D, Karppinen J, Fong DYT, Luk KDK, Cheung KMC. Modic changes of the lumbar spine: prevalence, risk factors, and association with 
disc degeneration and low back pain in a large-scale population-based cohort. Spine J. 2016;16(1): 32-41.

30. Han C, Kuang MJ, Ma JX, Ma XL. Prevalence of Modic changes in the lumbar vertebrae and their associations with workload, smoking and weight in northern China. Sci Rep. 2017;7:46341.

31. Urits I, Burshtein A, Sharma M, Testa L, Gold PA, Orhurhu V, et al. Low back pain, a comprehensive review: pathophysiology, diagnosis, and treatment. Curr Pain Headache Rep. 2019;23(3):23.

32. Kleinstück F, Dvorak J, Mannion AF. Are "structural abnormalities" on magnetic resonance imaging a contraindication to the successful conservative treatment of chronic nonspecific low back pain? Spine (Phila Pa 1976). 2006;31(19):2250-7.

33. Buttermann GR. The effect of spinal steroid injections for degenerative disc disease. Spine J. 2004;4(5):495-505.

34. Fayad F, Lefevre-Colau M-M, Rannou F, Quintero N, Nys A, Macé Y, et al. Relation of inflammatory Modic changes to intradiscal steroid injection outcome in chronic low back pain. Eur spine J. 2007;16(7):925-31.

35. Antonacci MD, Mody DR, Heggeness MH. Innervation of the human vertebral body: a histologic study. J Spinal Disord. 1998;11(6):526-31.

36. Torkki M, Majuri M-L, Wolff H, Koskelainen T, Haapea M, Niinimäki J, et al. Osteoclast activators are elevated in intervertebral disks with Modic changes among patients operated for herniated nucleus pulposus. Eur spine J. 2016;25(1):207-16.

37. Klawitter M, Hakozaki M, Kobayashi H, Krupkova O, Quero L, Ospelt C, et al. Expression and regulation of toll-like receptors (TLRs) in human intervertebral disc cells. Eur spine J. 2014;23(9):1878-91.

38. Wuertz K, Vo N, Kletsas D, Boos N. Inflammatory and catabolic signalling in intervertebral discs: the roles of NF- $\kappa \mathrm{B}$ and MAP kinases. Eur Cell Mater. 2012;23:103-20.

39. Piccinini AM, Midwood KS. DAMPening inflammation by modulating TLR signalling. Mediators Inflamm. 2010;2010:1-21.

40. Mills KHG. TLR-dependent $\mathrm{T}$ cell activation in autoimmunity. Nat Rev Immunol. 2011;11(12): 807-22.

41. Baum T, Yap SP, Karampinos DC, Nardo L, Kuo D, Burghardt AJ, et al. Does vertebral bone marrow fat content correlate with abdominal adipose tissue, lumbar spine bone mineral density, and blood biomarkers in women with type 2 diabetes mellitus? J Magn Reson Imaging. 2012;35(1):117-24.

42. Karchevsky M, Schweitzer ME, Carrino JA, Zoga A, Montgomery D, Parker L. Reactive endplate marrow changes: a systematic morphologic and epidemiologic evaluation. Skeletal Radiol. 2005;34(3):125-9.

43. Thomas GPL, Hemmrich K, Abberton KM, McCombe D, Penington AJ, Thompson EW, et al. Zymosan-induced inflammation stimulates neoadipogenesis. Int J Obes (Lond). 2008;32(2):239-48.

44. Monden M, Koyama H, Otsuka Y, Morioka T, Mori $\mathrm{K}$, Shoji T, et al. Receptor for advanced glycation end products regulates adipocyte hypertrophy and insulin sensitivity in mice: involvement of Toll-like receptor 2. Diabetes. 2013;62(2):478-89.

45. Lim YZ, Wang Y, Wluka AE, Davies-Tuck ML, Hanna F, Urquhart DM, et al. Association of obesity and systemic factors with bone marrow lesions at the knee: a systematic review. Semin Arthritis Rheum. 2014;43(5):600-12.

46. Zhao Q, Cheng L, Yan H, Deng S, Zhao J, Liu Z, et al. The anatomical study and clinical significance of the sinuvertebral nerves at the lumbar levels. Spine (Phila Pa 1976). 2020;45(2):61-6.

47. Shayota B, Wong TL, Fru D, David G, Iwanaga J, Loukas $M$, et al. A comprehensive review of the sinuvertebral nerve with clinical applications [Internet]. Anatomy Cell Biol. Korean. 2019; 52: 128-33. pmc/articles/PMC6624329/?report=abstract. Accessed 29 Sep 2020

48. Degmetich S, Bailey JF, Liebenberg E, Lotz JC. Neural innervation patterns in the sacral vertebral body. Eur Spine J. 2016;25(6):1932-8.

49. Zehra U, Cheung JPY, Bow C, Crawford RJ, Luk $\mathrm{KDK}, \mathrm{Lu} \mathrm{W}$, et al. Spinopelvic alignment predicts disc calcification, displacement, and Modic changes: Evidence of an evolutionary etiology for clinically-relevant spinal phenotypes. JOR Spine. 2020;3(1):e1083.

50. Brown MF, Hukkanen MV, McCarthy ID, Redfern DR, Batten JJ, Crock HV, et al. Sensory and sympathetic innervation of the vertebral endplate in patients with degenerative disc disease. J Bone Jt Surg Br. 1997;79(1):147-53.

51. Ware J, Kosinski M, Keller S. SF-36 Physical and mental health summary scales: a user's manual. A user's Man. 1994.

52. Becker S, Hadjipavlou A, Heggeness MH. Ablation of the basivertebral nerve for treatment of back pain: a clinical study. Spine J. 2017;17(2):218-23. 
53. Herdman M, Gudex C, Lloyd A, Janssen M, Kind P, Parkin D, et al. Development and preliminary testing of the new five-level version of EQ-5D (EQ-5D5L). Qual Life Res. 2011;20:1727-36.

54. Truumees E, Macadaeg K, Pena E, Arbuckle J, Gentile J, Funk R, et al. A prospective, open-label, single-arm, multi-center study of intraosseous basivertebral nerve ablation for the treatment of chronic low back pain. Eur Spine J. 2019;28(7): 1594-602.

55. Modic MT, Steinberg PM, Ross JS, Masaryk TJ, Carter JR. Degenerative disk disease: assessment of changes in vertebral body marrow with MR imaging. Radiology. 1988;166(1 Pt 1):193-9.

56. Fairbank J, Couper J, Davies J, O'Brien J. The Oswestry low back pain disability questionnaire. Physiotherapy. 1980;66(8):271-3.

57. Freyd M. The graphic rating scale. J Educ Psychol. 1923;14(2):83-102.

58. Fischgrund JS, Franke ARJ, Kitchel RSS, Yeung HBC. Intraosseous basivertebral nerve ablation for the treatment of chronic low back pain: a prospective randomized double-blind sham-controlled multi-center study. Eur Spine J. 2018;27(5):1146-56.

59. Fischgrund JS. Answer to the letter to the editor of Y. Li et al. concerning " Intraosseous basivertebral nerve ablation for the treatment of chronic low back pain: a prospective randomized double-blind sham-controlled multi-center study " by Fischgrund JS, et al. [Eur Spine J; (2018) 27(5): 1146-1156]. Eur Spine J. 2019;28(9):2224.

60. Scott JW. Scott's parabola. BMJ. 2001;323(7327): 1477.

61. Wong DA. Basivertebral nerve ablation: does the path followed suggest this technology is ready for adoption into clinical practice?: COMMENTARY ON: Khalil J et al. A prospective, randomized, multicenter study of intraosseous basivertebral nerve ablation for the tr. Spine J. 2020;20:154-5.
62. Deyo RA, Smith DHM, Johnson ES, Donovan M, Tillotson CJ, Yang X, et al. Opioids for back pain patients: primary care prescribing patterns and use of services. J Am Board Fam Med. 2011;24(6): 717-27.

63. Markman JD, Rhyne AL, Sasso RC, Patel AA, Hsu WK, Fischgrund JS, et al. Association between opioid use and patient-reported outcomes in a randomized trial evaluating basivertebral nerve ablation for the relief of chronic low back pain. Clin Neurosurg. 2020;86:343-7.

64. Macnab I. Negative Disc Exploration. An analysis of the causes of nerve-root involvement in sixty-eight patients. J Bone Joint Surg Am. 1971;53(5):891-903.

65. Kim HS, Adsul N, Yudoyono F, Paudel B, Kim KJ, Choi $\mathrm{SH}$, et al. Transforaminal epiduroscopic basivertebral nerve laser ablation for chronic low back pain associated with Modic changes: a preliminary open-label study. Pain Res Manag. 2018;2018:6857983

66. Kim HS, Wu PH, Jang IT. Lumbar degenerative disease part 1: anatomy and pathophysiology of intervertebral discogenic pain and radiofrequency ablation of basivertebral and sinuvertebral nerve treatment for chronic discogenic back pain: a prospective case series and review of literature. Int J Mol Sci. 2020;21(4):1483.

67. Adams MA, Roughley PJ. What is intervertebral disc degeneration, and what causes it? Spine (Phila $\mathrm{Pa}$ 1976). 2006;31(18):2151-61.

68. Ito K, Creemers L. Mechanisms of intervertebral disk degeneration/injury and pain: a review. Glob Spine J. 2013;3(3):145-52.

69. Wu PH, Kim HS, Jang IT. Intervertebral disc diseases PART 2: a review of the current diagnostic and treatment strategies for intervertebral disc disease. Int J Mol Sci. 2020;22:2136. 